\title{
Australia's earliest tetrapod swimming traces from the Hawkesbury Sandstone (Middle Triassic) of the Sydney Basin
}

\author{
Roy M. Farman ${ }^{1,2}$ () and Phil R. Bell ${ }^{2}$ (1) \\ ${ }^{1}$ School of Biological, Earth and Environmental Sciences, University of New South Wales, Sydney, New South Wales, 2052, Australia \\ $<$ r.farman@student.unsw.edu.au> \\ ${ }^{2}$ School of Environmental and Rural Science, University of New England, Armidale, New South Wales, 2351, Australia <pbel123@une.edu. \\ au>
}

\begin{abstract}
The Hawkesbury Sandstone (Hawkesbury Series, Sydney Basin) on the southeastern coast of New South Wales, Australia, preserves a depauperate but important vertebrate tetrapod body-fossil record from the Early and Middle Triassic. As with many fossil sites around the world, the ichnological record has helped to shed light on the paleoecology of this interval. Herein, we investigate historical reports of a trackway pertaining to a putative short-tailed reptile found at Berowra Creek in the 1940s. Reinvestigation of the surviving track-bearing slabs augmented by archival photographs of the complete trackway, suggests that these impressions, which consist primarily of didactyl tracks (plus less common monodactyl and tridactyl traces), represent the earliest example of a swimming tetrapod found in Australia. Another isolated specimen (possibly from a nearby locality at Annangrove) appears to represent similar didactyl swim traces of a second, larger individual. Although the identities of the trackmakers are unknown, the Berowra Creek individual had an estimated body length of between $\sim 80 \mathrm{~cm}$ (short-coupled) and $1.35 \mathrm{~m}$ (long-coupled), and produced the subaqueous trackway while travelling upslope (against the current) on a sandbar within a braided river system of the Hawkesbury Sandstone. These trackways partially resemble amphibian swim traces in the so-called Batrachichnus C Lunichnium continuum, but appear to represent a unique locomotion trace. This reanalysis of the Berowra Creek trackway provides insight into the locomotion of tetrapods of the Triassic Hawkesbury Series, which remains a poorly understood aspect of their life history.
\end{abstract}

\section{Introduction}

Ichnites are an important source of biological information that can be used to fill the gaps often left from the incomplete bodyfossil record (Thulborn, 1990; Lockley and Meyer, 2000; Martin, 2014). Although many tracks cannot be assigned to a given species or even genus, tracks can be useful for higher-level taxonomy, providing evidence for certain taxa that might not be evident from body fossils in a given stratigraphic layer (Retallack, 1996; Lucas, 1998; Klein and Lucas, 2010b).

On the eastern coast of New South Wales, the Hawkesbury Series (Sydney Basin) is regarded as the best example of Australia's Early to Middle Triassic terrestrial record (Kear and Hamilton-Bruce, 2011). Nevertheless, vertebrate body fossils from this interval are extremely rare. The Narrabeen Groupthe lowest subdivision of the Hawkesbury Series-preserves several temnospondyl amphibians, including Platycepsion wilkinsoni Stephens, 1887, the holotype of 'Parotosaurus wadei' Damiani, 2001 (= Watsonisuchus sp.), and the capitosaurid Bulgosuchus gargantua Damiani, 1999 (Stephens, 1887; Damiani and Warren, 1997; Damiani, 1999, 2001).

The overlying Hawkesbury Sandstone has produced one identifiable temnospondyl-Subcyclotosaurus brookvalensis Watson, 1958 (Stephens, 1887; Watson, 1958; Cosgriff, 1973; Retallack et al., 2011). The youngest subdivision of the Hawkesbury Series - the Wiannamatta Group_includes three amphibians: Notobrachyops picketti Cosgriff, 1973, Microposaurus averyi Warren, 2012, and Paracyclotosaurus davidi Watson, 1958 (Watson, 1958; Cosgriff, 1973; Warren, 2012). Unlike the other temnospondyls from the Sydney Basin, Paracyclotosaurus davidi is represented by a nearly complete skeleton (Watson, 1958) with a total estimated body length of $2.08 \mathrm{~m}$ (Retallack et al., 2011). Only the capitosaurid Bulgosuchus gargantua might have been larger, with an estimated length of $2.3 \mathrm{~m}$ (Damiani, 1999). All other temnospondyl materials represent individuals $<\sim 20 \mathrm{~cm}$ in length, although $M$. averyi might have been up to $1.45 \mathrm{~m}$ in total length (Warren, 2012).

Reptiles from the Sydney Basin are exclusively represented by two associated anterior dorsal vertebrae from the Bulgo Sandstone (Narrabeen Group). Although initially identified as a possible proterosuchid (Kear, 2009), they were subsequently identified as an indeterminate Erythrosuchidae (Ezcurra, 2016).

Trackways augment the tetrapod body-fossil record from the Sydney Basin (Fletcher, 1948; Sherwin, 1969; Pepperell and Grigg, 1974; Retallack, 1996). A large amphibian trackway (glenoacetabular length $=106 \mathrm{~cm}$ ) from the Wianamatta Group was described from a sewage tunnel at Macquarie Fields (Pepperell and Grigg, 1974) and therapsid footprints (Dicynodontipus bellambiensis Retallack, 1996) have been described from the upper Permian/Lower Triassic Coalcliff Sandstone (Retallack, 1996). The latter were interpreted as a possible species 
of Lystrosaurus based on scale impressions, claw marks, phalangeal formula (2-3-3-3-3), and a pentadactyl manus/pes (Retallack, 1996).

\section{The Berowra trackway}

In the 1940s, a trackway consisting of primarily didactyl manus and pes prints (AM F145167-F145171) was discovered by Geoffrey Scarrott at his sandstone quarry in the Sydney suburb of Berowra (Fig. 1.1, 1.2). These tracks were briefly described by Fletcher (1948) who determined that the tracks belonged to a short-tailed reptile based on the absence of a central tail furrow (tail drag). Curiously, Sherwin (1969), when referring to the Berowra trackway and a second sequence from the nearby suburb of Annangrove (also from the Hawkesbury Sandstone), noted rare tail-drag marks, but did not specify the specimen to which he was referring. The Annangrove specimen was never figured and no specimen number was given. In their popular book, Willis and Thomas (2005, p. 119) also briefly mentioned the Berowra trackway and interpreted 'the curved grooves as being the marks where the tail dragged across the ground behind the animal,' denoting a terrestrial origin for the Berowra tracks. The footprints were interpreted to have been made by an individual walking on soft wet sand on the shore of a lake or estuary subject to water fluctuations (Fletcher, 1948). Importantly, these tracks remain the only putative evidence of reptiles in the Hawkesbury Sandstone, although rare reptile remains (Erythrosuchidae gen. indet. sp. indet.) have been identified from the older Narrabeen Group (Kear, 2009; Ezcurra, 2016).

The Annangrove tracks briefly noted by Sherwin (1969) evidently consist of well-preserved, concave, epirelief molds that share similarly elongated didactyl digits to the Berowra trackway (Sherwin, 1969). The arrangement of these prints, ostensibly with faint and discontinuous tail-drag marks and the absence of belly-drag marks (Sherwin [1969] did not distinguish between the Berowra and Annangrove trackways in his interpretation), was interpreted to represent a stereospondyl amphibian similar to Platycepsion wilkinsoni or Paracyclotosaurus davidi (see Sherwin, 1969).

Since Fletcher's (1948) original report, increased taxonomic sampling from the Sydney Basin and the global proliferation of ichnological (including neontological) studies from the Triassic (Peabody, 1948; Lammers, 1964; Pepperell and Grigg, 1974; Damiani and Warren, 1997; McAllister and Kirby, 1998; Damiani, 1999, 2001; Kear, 2009; Thomson and Lovelace, 2014; Thomson and Droser, 2015a, b), affords the opportunity to reassess the origin of the Berowra trackway. Here, we describe the Berowra tracks in detail for the first time and, aided by photogrammetry and archival photographs, provide an alternative interpretation of the trackway.

\section{Geological and paleoenvironmental setting}

The Sydney Basin, on the southeastern coast of Australia, is made up of the Triassic Hawkesbury Series, which consists of four divisions (from oldest to youngest): the Narrabeen Group, the Hawkesbury Sandstone, the Mittagong Formation, and the Wianamatta Group (Fig. 2; Young, 1996; Damiani,
1999). The Anisian Hawkesbury Sandstone, which is the subject of this study, is up to $250 \mathrm{~m}$ thick and is characterized by meter-scale, quartz-rich, cross-bedded sandstones with minor interbedded shales (Herbert, 1980, 1983).

During the late Permian to Middle Triassic, tectonic uplift of the Lachlan Fold Belt in the southwestern part of the Sydney Basin led to down-dip deposition of quartzose sand, which formed the Hawkesbury Sandstone (Herbert, 1980). These sands were deposited by northeasterly flowing, high-energy braided rivers (Herbert, 1980; Totterdell et al., 2014) on a broad, energetic, moderately sloping alluvial plain (Miall and Jones, 2003).

During episodic periods of sea-level rise and fall (Herbert, 1980; Rust and Jones, 1987), some water bodies became cut off from the main river systems, creating isolated channels and pools of water (Herbert, 1997). These ponds, represented as shale lenses within the Hawkesbury Sandstone (Herbert, 1997), have produced most of Hawkesbury fauna, including fossils of Lagerstätten quality (Fletcher, 1948; Standard, 1969). On the other hand, the sandstone beds of the Hawkesbury Sandstone are usually considered unfossiliferous, with the exception of the Berowra Creek 'reptile tracks' and preserved microflora (Fletcher, 1948; Helby, 1969; Standard, 1969).

As with other exposures of the Hawkesbury Sandstone, rocks exposed at Scarrott's quarry at Berowra are laminated and can be split perfectly, which has led to their widespread use as local building material (Fletcher, 1948). Archival photographs (Fig. 1.1, 1.2) show clear, large-scale crossbedding exposed at Scarrott's quarry, which is characteristic of the Hawkesbury Sandstone and typical of lateral accretion and downstream accretionary surfaces on sandbars within a braided river system (Miall, 1977; Rust and Jones, 1987; Miall and Jones, 2003).

\section{Materials and methods}

To differentiate and avoid confusion with fully terrestrial conditions in dry or moist substrata (track, tracks, and trackway), McAllister (1989) proposed an alternate terminology for subaqueous traces made by buoyant tetrapods (footmark, footmarks, and traceway). This scheme has not been widely adopted and we herein employ traditional terminology (track, trackway) in keeping with its more common usage in the literature, while recognizing the subaqueous formation of the tracks described here (see Description and Discussion).

The Berowra trackway is distributed across nine sandstone slabs that were cemented together and put on public display at the Australian Museum in Sydney (Fig. 3.1); however, four of these slabs are now missing (Fig. 3.2). One of these slabs was located at the Kalkari Discovery Centre (in Ku-ring-gai Chase National Park, Mount Colah, New South Wales) but could not be accessed and the position of this slab within the sequence remains unknown. The remaining five slabs (AM F145167145171) include the partial counterpart (AM F145171) of a slab that had been cemented into the main track-bearing slab as part of the museum exhibit (Fig. 3.2, slabs E, F; Table 1). These two pieces (of which only the counterpart remains) are certainly related to the main sequence based on both lithology 

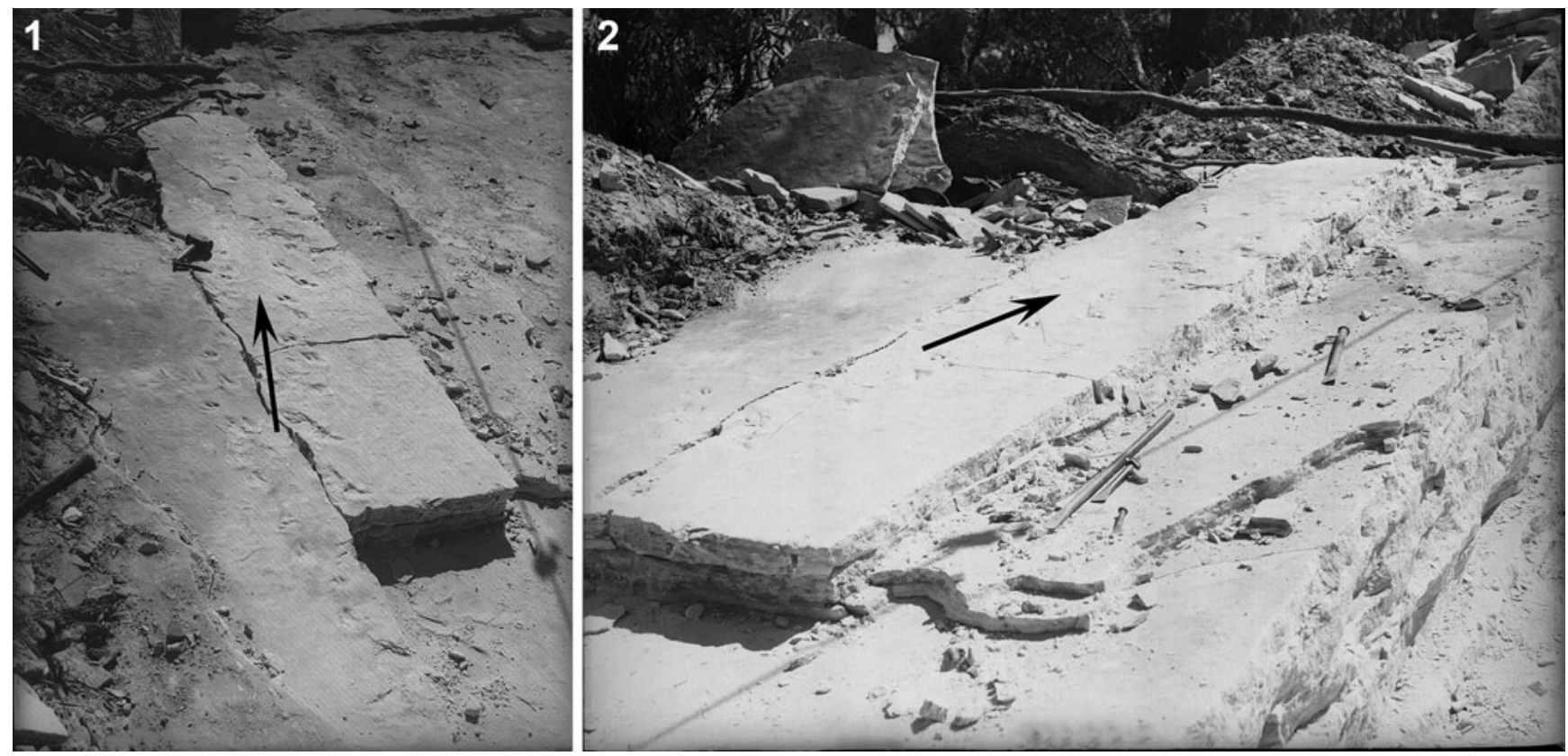

Figure 1. Archival photographs of the Berowra trackway (AM F145167-145171) during excavation at Geoffrey Scarrott's sandstone quarry in the 1940s. Clear crossbedding of the Hawkesbury Sandstone member is visible in (2). The direction of travel of the trackmaker is indicated by arrows. Photographs taken by Howard Hughes and acquired from the Archives of the Australian Museum.

and track morphology, but their precise relationship and where they potentially sit within the trackway remains unclear. One other slab (AM F145166; Fig. 4.1-4.4) found in storage together with an archival photo of the Berowra trackway preserves morphologically similar, but significantly larger, didactyl traces compared to the other slabs (AM F145167-145171; Figs. 4.14.4, 5.1-5.12); however, whether AM F145166 (Fig. 4.1-4.4) originated from the Berowra Creek locality, the Annangrove trackway described by Sherwin (1969), or another locality is unknown.
1

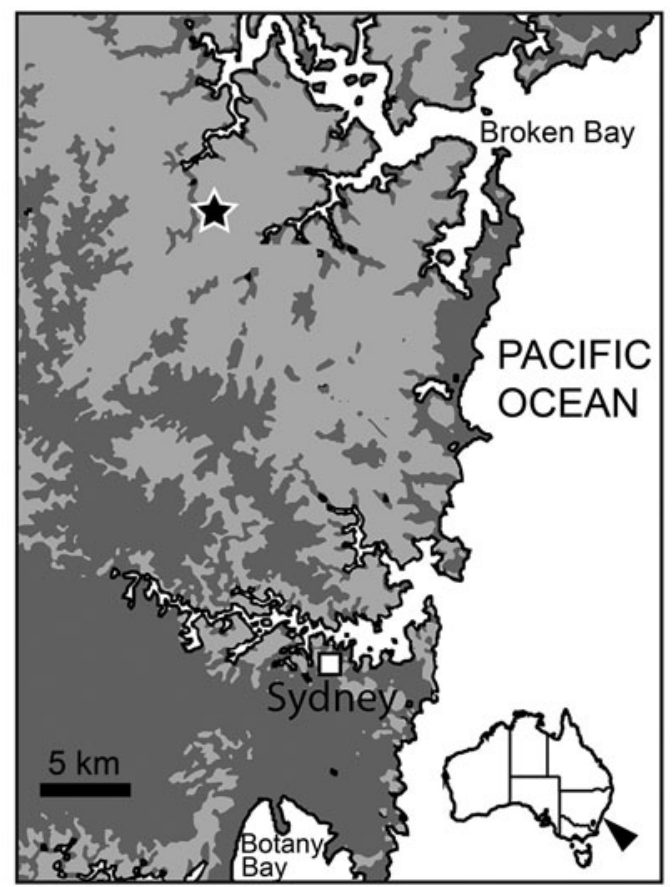

2

\begin{tabular}{|c|c|c|c|c|}
\hline \multicolumn{2}{|c|}{ CHRONOSTRATIGRAPHY } & \multicolumn{2}{|r|}{ CENTRAL EAST } & NORTH EAST \\
\hline \multirow{5}{*}{ 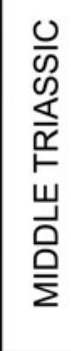 } & LADINIAN & \multicolumn{2}{|r|}{$\begin{array}{l}\text { Wianamatta Group } \\
\text { Paracyclotosaurus davidi } \\
\text { Notobrachyops picketti } \\
\text { Microposaurus averyi }\end{array}$} & \\
\hline & \multirow{4}{*}{ ANISIAN } & \multicolumn{3}{|c|}{ Mittagong Formation } \\
\hline & & \multicolumn{3}{|c|}{$\begin{array}{l}\text { Hawkesbury Sandstone } \\
\text { Subcyclotosaurus brookvalensis } \\
\text { Berowra traceway }\end{array}$} \\
\hline & & \multirow{7}{*}{ 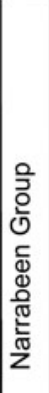 } & Newport Formation & \multirow{2}{*}{ Terrigal Formation } \\
\hline & & & Garie Formation & \\
\hline \multirow{3}{*}{ 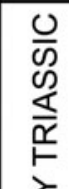 } & \multirow{5}{*}{$\begin{array}{l}\text { INDUAN- } \\
\text { OLENEKIAN }\end{array}$} & & Bald Hill Claystone & \multirow{2}{*}{$\begin{array}{l}\text { Platycepsion wilkinsoni } \\
\text { 'Parotosaurus wadei' }\end{array}$} \\
\hline & & & Bulgo Sandstone & \\
\hline & & & $\begin{array}{l}\text { Bulgosuchus garantua } \\
\text { Erythrosuchidae indet. }\end{array}$ & Patonga Claystone \\
\hline \multirow{2}{*}{ 䍃 } & & & $\begin{array}{l}\text { Erythrosuchidae indet. } \\
\text { Stanwell Park Clstn }\end{array}$ & Tuggerah Formation \\
\hline & & & Scarborough Clstn & Munmunorah Claystone \\
\hline \multirow{2}{*}{\multicolumn{2}{|c|}{ PERMIAN }} & & Wombarra Claystone & \multirow{2}{*}{ Dooralong Shale } \\
\hline & & & Coalcliff Sandstone & \\
\hline
\end{tabular}

Figure 2. (1) Map of the northeastern part of the Sydney Basin showing the Berowra Creek locality (star) and regional extent of the Hawkesbury Sandstone (light gray). Arrowhead on the inset map of Australia identifies the position of the Sydney Basin. (2) Chronostratigraphic chart of the Hawkesbury Series showing stratigraphic position of the Berowra trackway and all significant vertebrate body fossils (redrawn and modified from Damiani, 1999). Clstn $=$ Claystone. 


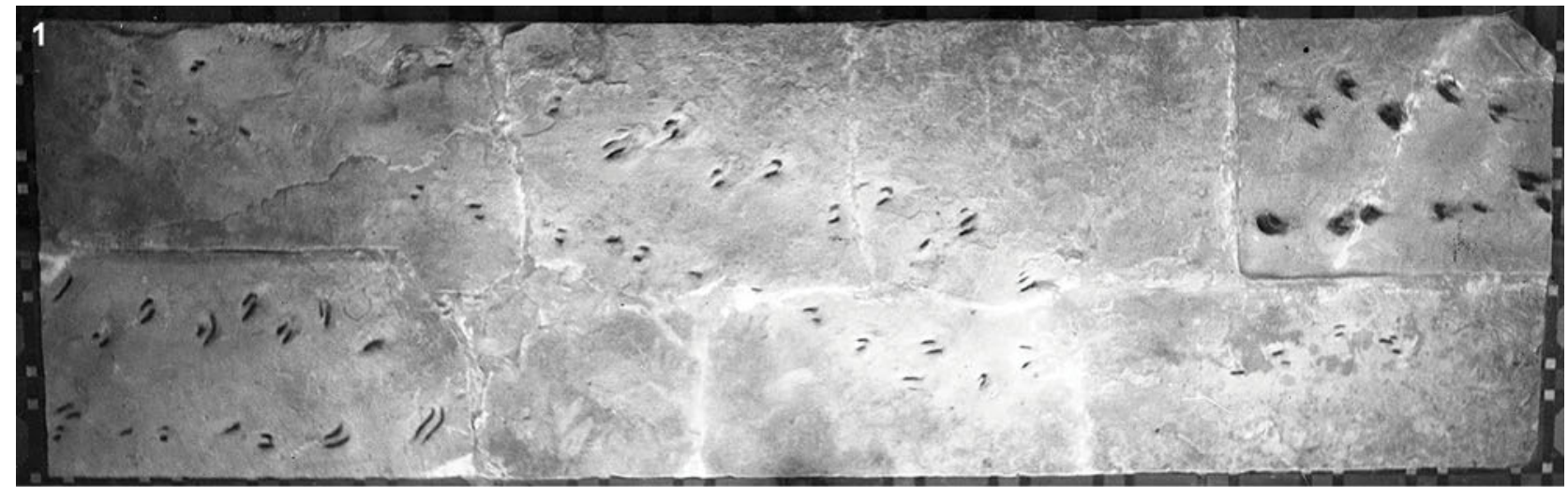

2

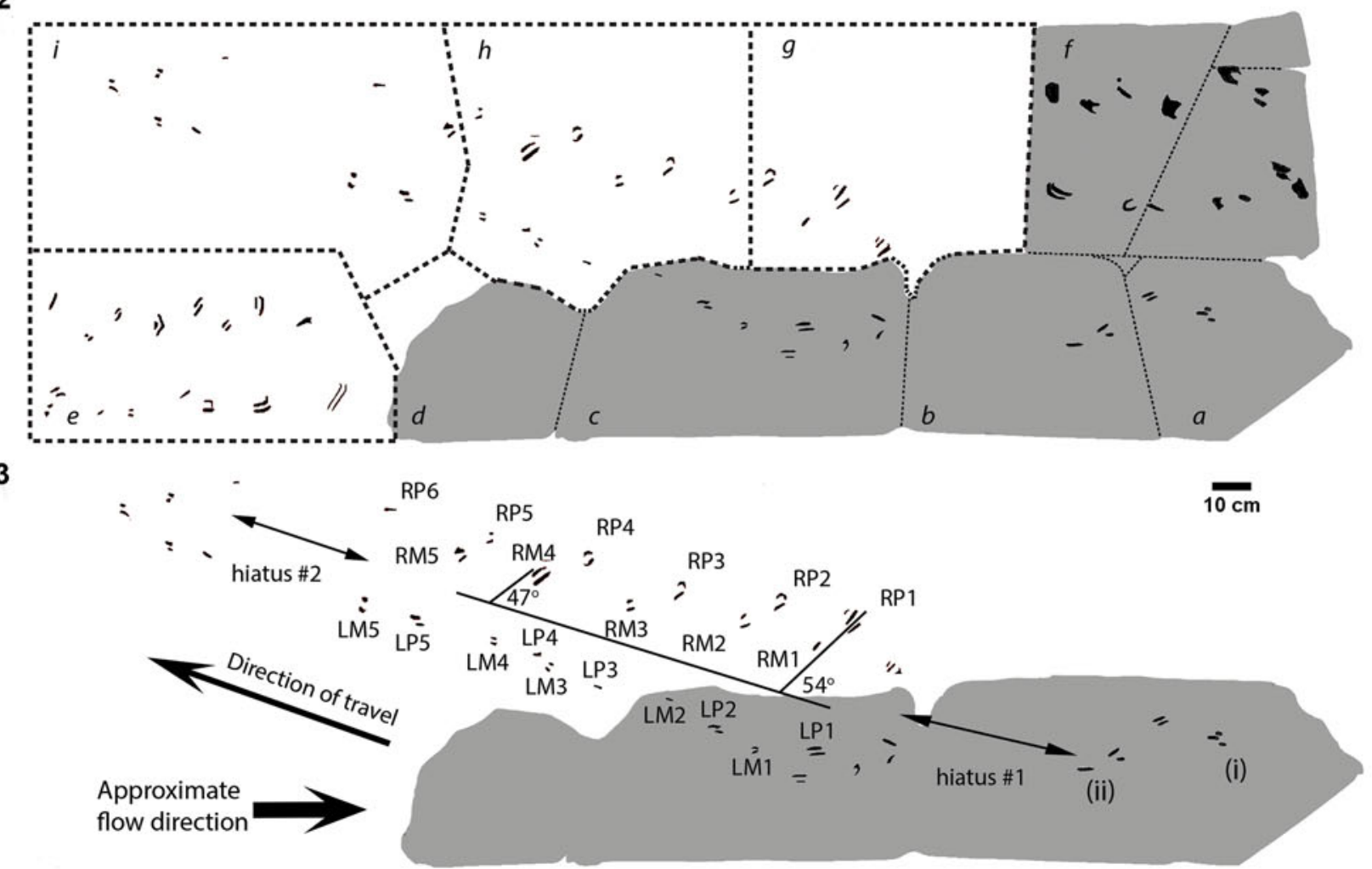

4
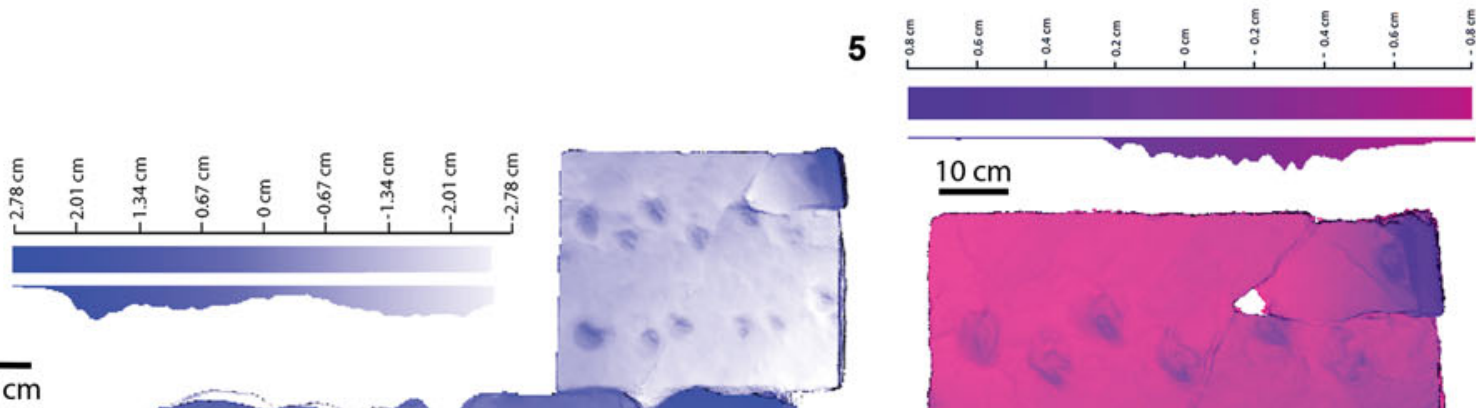

$\underline{10 \mathrm{~cm}}$
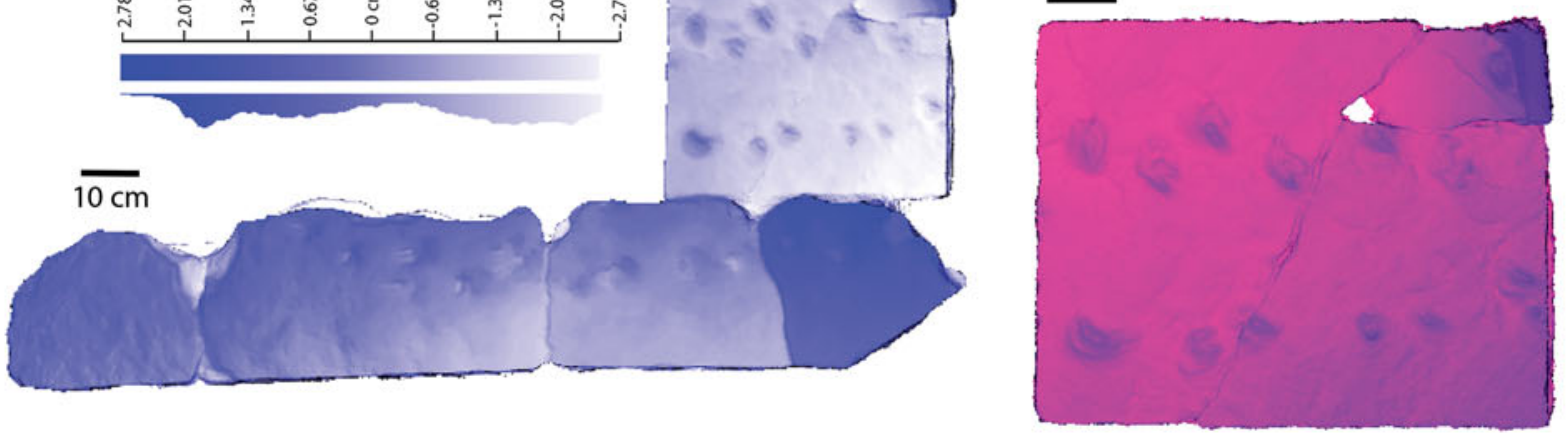
Figure 3. The Berowra trackway (AM F145167-145171): (1) Historic photo taken in the 1950s showing the trackway in its entirety ( 4.2 m long) while on display at the Australian Museum (photograph from the Archives of the Australian Museum). (2) Interpretive drawing of the entire trackway showing the missing slabs (white) and those that were available for firsthand observation (gray). Dashed lines demarcate the individual slabs here designated a-i. Slabs e and $\mathrm{f}$ represent the part and incomplete counterpart of the same traces that were cemented into the display, although their precise placement with respect to the main trackway is unknown. Heavy dashed lines represent hypothetical boundaries observed in archival images; fine dashed lines represent firsthand observations of boundaries between slabs. (3) Interpretive illustration of the main trackway with key features and measurements noted. Note that the right-sided manus and pes impressions are angled inward toward the midline of the trackway. The two highest angle values are recorded. Roman numerals identify the tridactyl (i) and monodactyl (ii) traces shown in Fig. 5. See text for explanation of hiatus \#1 and hiatus \#2. Scale bar here pertains to (1-3). (4) Height map of the surviving slabs a, b, c, d, and f. (5) Height map of slab $f(A M$ F145171) representing the positive epirelief counterpart to the missing slab e. $L M=$ left manus; $L P=$ left pes; $R M=$ right manus; $R P=$ right pes.

Archival images provided by the Australian Museum were vital in reconstruction of the trackway and were the basis for many measurements. Photogrammetric models were constructed of the available slabs (Fig. 3.2, slabs A-D; AM F145167-145170), as well as two additional slabs (AM F145171, Fig. 3.2, slab F; AM F145166, Fig. 4). Photographs were taken using a Sony Alpha 6000 DSLR camera and input into Agisoft Photoscan Professional (Agisoft LLC) to create 3D models. Meshlab (Visual Computing Lab) was used to create lighting for the 3D models to show depth. Digital elevation models were created using CloudCompare (http://www.cloudcompare.org/); however, the maps were produced with different colors to best represent negative/positive ichnites. Direct measurements of the slabs (AM F145166, 145167-145171) were used to calibrate the digital measurement tool using ImageJ (https://imagej.net) to obtain additional measurements from both trackways. Standard track parameters were used for pace, stride, glenoacetabular length, trackway width, and digit length. For the didactyl traces, digits were identified as digit III and IV on the basis that these digits penetrate deepest into the substratum (sensu Leonardi, 1987). Pace angulation and digit divarication values were measured using ImageJ (Fig. 3.3).

Slabs A, B, C, D, and F (Fig. 3.2; AM F145167-145171) were available for firsthand study and descriptions of the missing slabs (Fig. 3.3, slabs E, G, H, and I) were based solely on archival photos (Fig. 3.1). Manus and pes impressions were determined based on the trackways of a large sample of extinct (Peabody, 1948; Baird, 1957; Ginsburg et al., 1966; Sarjeant and Stringer, 1978; Azerêdo, 1993; Azerêdo et al., 1995; Wilson and Carrano, 1999; Lockley and Meyer, 2000; Day et al., 2002; Rogers and Wilson, 2005; Santos et al., 2009; Klein and Lucas, 2010a; Marchetti et al., 2014) and extant tetrapods (Huene, 1913; Padian and Olsen, 1984a, b; Carpenter, 2009) in which

Table 1. Lengths ( $\mathrm{cm}$ ) of digits 1 and 2 of the part (missing) and counterpart (AM F145171) of the Berowra trackway; digits ordered medially to laterally, which might not represent the actual order. Negative ichnites (molds) were measured digitally. Positive ichnites (casts) were measured firsthand; measurements marked with an asterisk (*) are highly tentative because the borders of the digits were not clear.

\begin{tabular}{lcclrr}
\hline Molds & Digit 1 & Digit 2 & Casts & Digit 1 & Digit 2 \\
\hline $\mathbf{1 a}$ & 3.5 & 2.7 & $\mathbf{2 a}$ & 3.9 & 2.7 \\
$\mathbf{1 b}$ & 5.6 & 4.1 & $\mathbf{2 b}$ & $* 5.3$ & $* 4.0$ \\
$\mathbf{1 c}$ & 8.4 & 2.8 & $\mathbf{2 c}$ & $* 7.7$ & $* 2.7$ \\
$\mathbf{1 d}$ & 4.6 & 3.5 & $\mathbf{2 d}$ & 5.2 & 3.5 \\
$\mathbf{1 e}$ & 2.8 & 1.5 & $\mathbf{2 e}$ & 2.8 & 3.8 \\
$\mathbf{1 f}$ & 4.4 & 5.8 & $\mathbf{2 f}$ & 4.4 & 5.7 \\
$\mathbf{1 g}$ & 2.5 & 2.9 & $\mathbf{2 g}$ & 2.5 & 2.9 \\
$\mathbf{1 h}$ & 3.9 & - & $\mathbf{2 h}$ & $* 4.2$ & - \\
$\mathbf{1 i}$ & 1.1 & 1.9 & $\mathbf{2 i}$ & $* 1.1$ & $* 2.1$ \\
$\mathbf{1 j}$ & 3.5 & - & $\mathbf{2 j}$ & 3.6 & - \\
$\mathbf{1 k}$ & 4.2 & 3.4 & $\mathbf{2 k}$ & 4.3 & 3.4 \\
$\mathbf{1 1}$ & 2.2 & 2.1 & $\mathbf{2 l}$ & $* 2.2$ & $* 2.6$ \\
\hline
\end{tabular}

prints closest to the midline are interpreted as the manus and the pes prints are farther away from the midline.

Repository and institutional abbreviation.-Specimens and archival images examined during this study are deposited in the Australian Museum (AM), Sydney.

\section{Results}

Description of the Berowra trackway (AM F145167F145171).- The main part of the trackway consists of a series of concave epirelief molds, however, one slab (Fig. 3.2, slab F; AM F145171) forming the counterpart of slab E (the latter of which is now missing) consists of convex hyporelief casts (Table 1). From the surviving slabs and archival photographs, there are no signs of any tail- or body-drag marks, as was also noted by Fletcher (1948, but in contradiction to Willis and Thomas, 2005 and possibly Sherwin, 1969). Based on archival images of the trackway during excavation (Fig. 1.1, 1.2), the trackmaker was travelling upslope (from right to left in Fig. 3.1-3.4) as was also noted by Fletcher (1948).

At least 35 individual manus/pes traces form a discontinuous sequence travelling from right to left (Fig. 3.1-3.3). An additional 29 tracks are preserved in the part and counterpart (collectively) that were cemented into the display panel (Fig 3.2; slabs E and F; Table 1). Individual tracks are primarily didactyl and subdigitigrade, although less common monodactyl and tridactyl impressions are also present (Figs. 3.1-3.5, 5.1-5.12). Low crescents of displaced sediment are present immediately posterior to many of the traces (Fletcher, 1948). Digit traces of both mani and pedes generally consist of isolated impressions (i.e., the hypex between digits and the heel is never preserved) of variable lengths (mean right manus $=2.8 \mathrm{~cm}, \mathrm{~N}=5$; mean right pes $=3.0 \mathrm{~cm}, \mathrm{~N}=6$ ) with sharp-to-rounded terminations (Table 2). Only the outerdigit trace of the pes appears to differ from this general configuration in which it sometimes forms a relatively short, arcuate (concave medially) impression. Both manual and pedal traces (excluding monodactyl traces) have variable digit-divarication angles ranging from acute $\left(13-44^{\circ}\right)$ to subparallel or even convergent (Fig. 3.1-3.3; Table 3).

The trackway is discontinuous, stopping and starting abruptly at two separate points in the succession. The trackway commences with a series of four mono- to tridactyl traces that all appear to pertain to the left side of the animal based on their alignment with the remainder of the trackway. Based on the truncated edge of the preserved slabs (Fig. 3.2, slabs A and B), it is unclear whether the right-sided traces were never preserved or if they were simply not collected. A hiatus in the trace progression follows the fourth trace before it resumes with a series of 

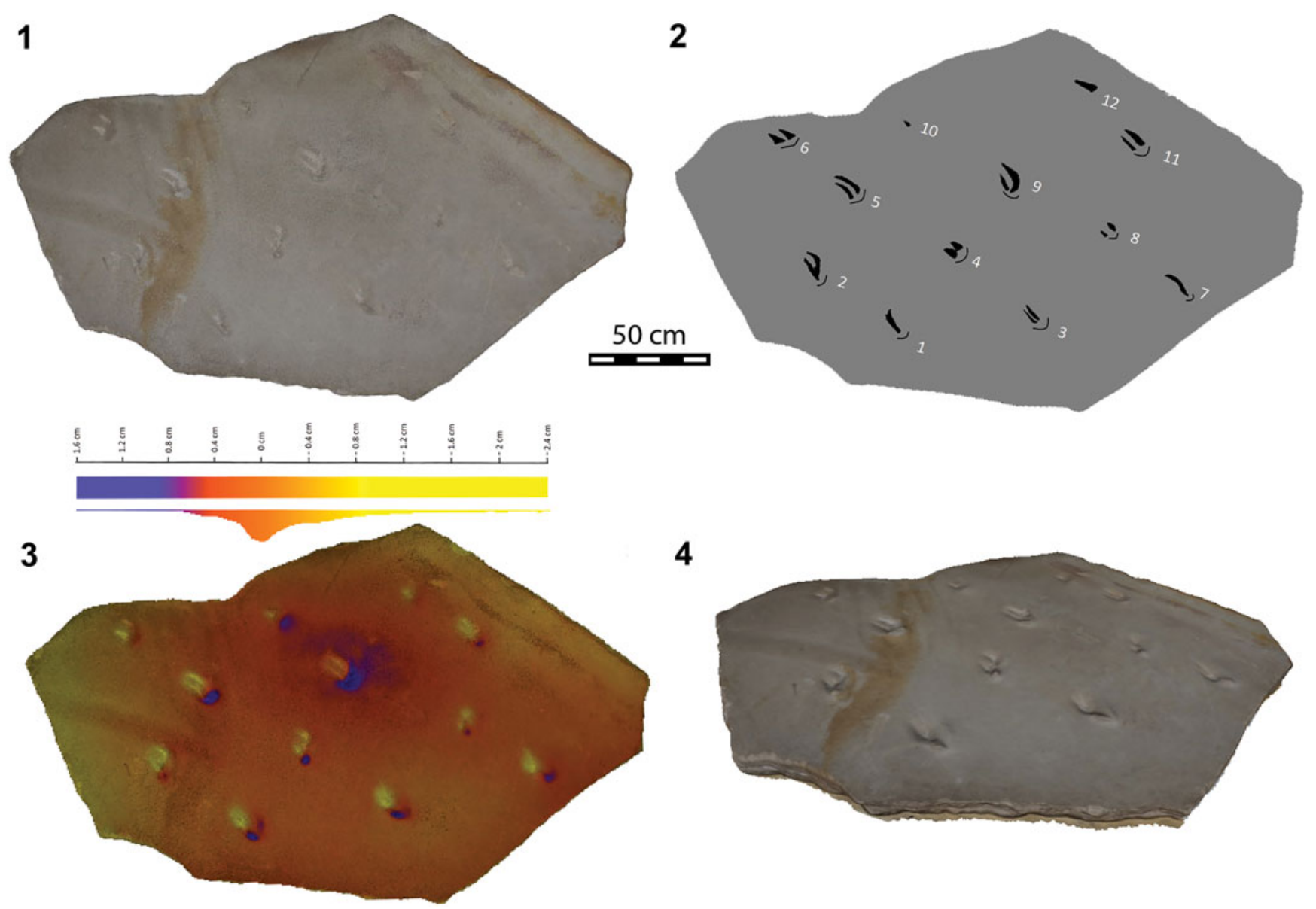

\section{4}

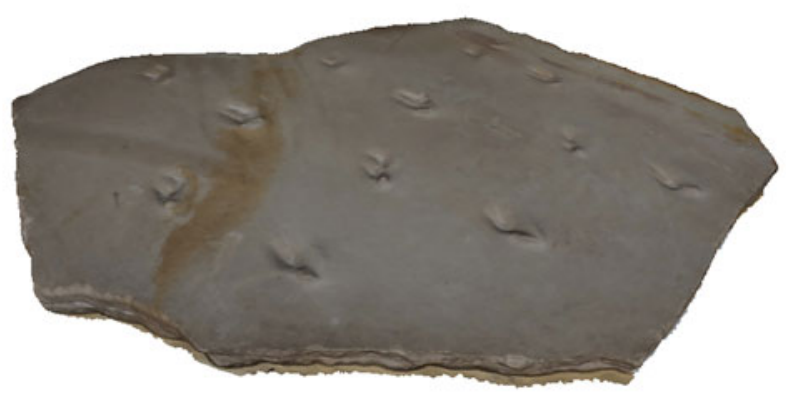

Figure 4. Isolated slab of primarily didactyl tracks (AM F145166), possibly representing the 'Annangrove tracks' reported by Sherwin (1969): (1, 4) textured photogrammetric model, in top (1) and oblique (4) views; (2) interpretive illustration of (1); (3) height map of (1). Numbers in (2) correspond to individual impressions; see numbering scheme in Table 4.

five-to-six manus and pes pairings (Fig. 3.3, hiatus \#1). Left and right manus/pes traces are asymmetrical: those on the right side are inwardly rotated (up to $54^{\circ}$ to the direction of travel), whereas those on the left are subparallel or outwardly rotated relative to the trackway midline (Fig. 3.3; Table 3). A second hiatus follows before the trackway resumes with a less distinct series of five mono- to didactyl traces, although identification of distinct manus/pes pairings was not possible because the relevant slabs are now missing and could not be observed firsthand (Fig. 3.3, hiatus \#2).

Estimates of pes/manus stride and pace lengths were similar but varied considerably between manus and pes pairings (Table 3). Trackway width $(31 \mathrm{~cm})$ is between $\sim 80 \%$ and $60 \%$ of the glenoacetabular length $(37.1 \mathrm{~cm}$ based on short coupling; $50 \mathrm{~cm}$ based on long coupling) and can therefore be considered wide gauge. Manus pace angulation $\left(46.8-82.9^{\circ}\right)$ is, on average, greater than that of the pes $\left(37.1-63.7^{\circ}\right)$, consistent with the track configuration of reptiles and amphibians (Leonardi, 1987). Some evidence of homopody throughout the trackway is present between the manus and pes pairings, although individual traces are highly variable and not necessarily reflective of the true manus/pes morphology. Phalangeal pad impressions and distinct claw marks are not preserved.
Description of AM F145166.-An additional slab identified during this study has the same coloration and sedimentary composition as, but probably does not pertain to, the Berowra trackway (Fig. 4.1-4.4). Sherwin (1969) briefly described a trackway from Annangrove that had similar traces to the Berowra trackway. It is possible that the current specimen (AM F145166) is that described by Sherwin (1969) although he never figured it or provided a specimen number to help confirm this possibility. Regardless, the sandstone matrix in which the traces are preserved appears virtually identical to the Berowra slabs (AM F145167-145171), suggesting that it also derives from the Hawkesbury Sandstone (Fig. 4.1-4.4). The specimen consists of monodactyl $(\mathrm{N}=4)$ and didactyl $(\mathrm{N}=8)$ traces (concave epirelief) that are arranged into four equally spaced 'rows,' each row consisting of alternating short and long traces oriented parallel to the presumed direction of travel (i.e., each short/long trace is parallel to the 'row' that they are part of) (Fig. 4.1-4.4). Thus, it is possible that the trackway represents the passage of as many as three adjacent individuals with the track numbers 1-2, 3-10, and 11-12 of Fig 4.2 representing different individuals; however, unambiguous distinction of left and right or even between manus and pes is not possible (see below). 

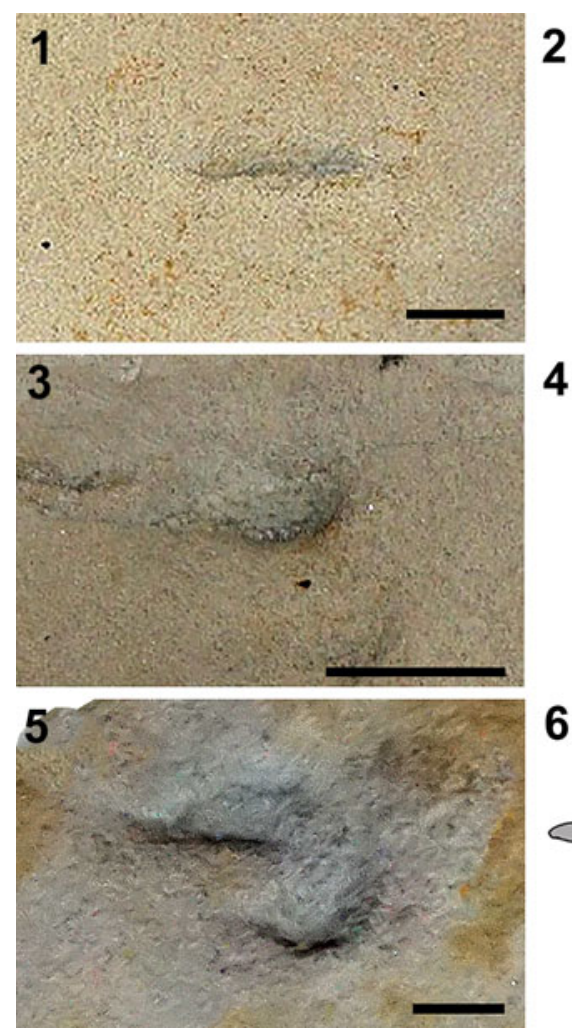
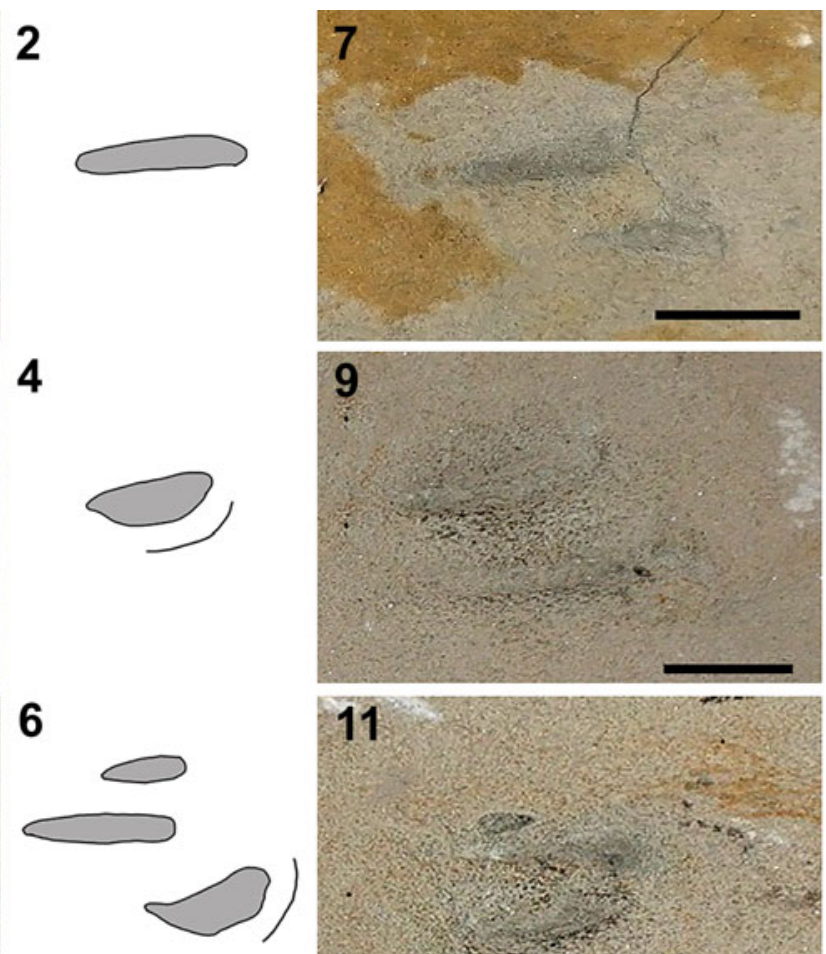

8

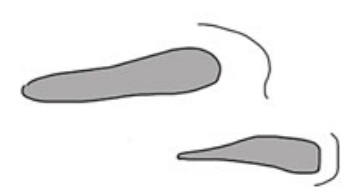

10
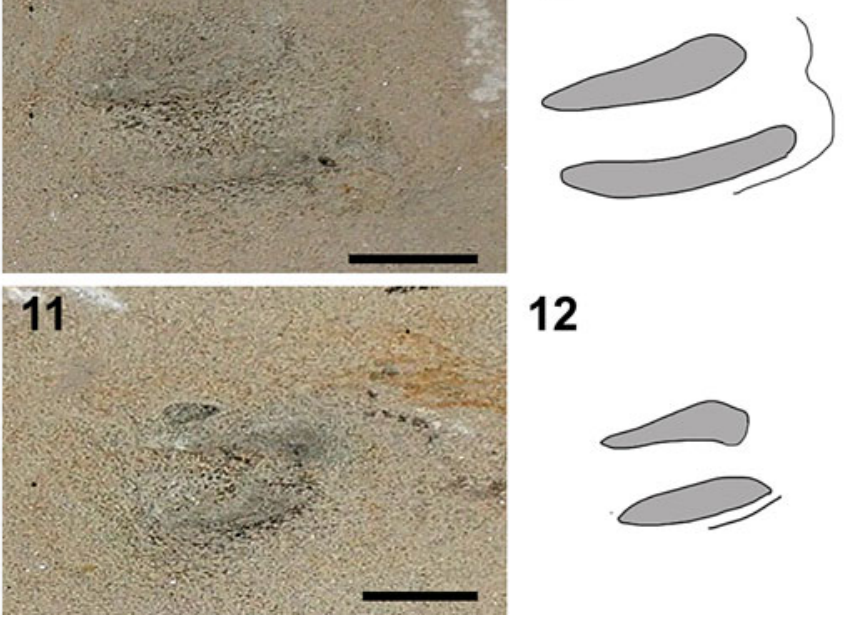

12

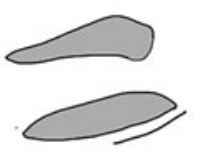

Figure 5. Photographs and interpretive outlines of representative monodactyl (1-4), didactyl (7-12), and tridactyl (5-6) traces from the Berowra trackway (AM F145167-145171). Photographs $(\mathbf{1}, \mathbf{3}, \mathbf{5}, \mathbf{7}, \mathbf{9}, \mathbf{1 1})$ and interpretive outlines $(\mathbf{2}, \mathbf{4 , 6}, \mathbf{8}, \mathbf{1 0}, \mathbf{1 2})$ correspond to the tracks labelled in Fig. 3.3: $(\mathbf{1 , 2})$ ii; $(\mathbf{3 , 4}) \mathrm{LM} 2$; $(\mathbf{5}, \mathbf{6}) \mathrm{I} ;(\mathbf{7}, \mathbf{8}) \mathrm{LP} 2 ;(\mathbf{9}, \mathbf{1 0}) \mathrm{LP} 1 ;(\mathbf{1 1}, \mathbf{1 2}) \mathrm{LM} 1$. L = left; M = manus; $\mathrm{P}=$ pes. Scale bars $=2 \mathrm{~cm}$.

Table 2. Digit lengths and means (cm) for AM F145167-145170. Digits are numbered from medial to lateral as preserved and might not represent the actual digit position on the skeleton. $*=$ firsthand measurements (all other measurements taken using ImageJ); LM = left manus; LP = left pes; $\mathrm{RM}=$ right manus; $\mathrm{RP}=$ right pes.

\begin{tabular}{lccc}
\hline Trace & Digit I & Digit II & Digit III \\
\hline RP1 & 3.5 & 4.3 & 1.8 \\
RP2 & 2.9 & 2.9 & - \\
RP3 & 2.8 & 2.4 & - \\
RP4 & 2.6 & 2.7 & - \\
RP5 & 2.3 & 1.6 & - \\
RP6 & 3.5 & 3.2 & - \\
RM1 & 2.8 & - & - \\
RM2 & 2.5 & 2.3 & - \\
RM3 & 2.0 & 1.7 & 2.3 \\
RM4 & 4.5 & 2.7 & - \\
RM5 & 2.3 & 2.0 & - \\
LP1 & $* 2.9$ & $* 3.3$ & - \\
LP2 & $* 2.9$ & $* 1.6$ & - \\
LP3 & 3.0 & - & - \\
LP4 & 2.9 & - & - \\
LP5 & 2.8 & 1.7 & - \\
LM1 & $* 2.7$ & $* 2.5$ & - \\
LM2 & $* 2.7$ & - & - \\
LM3 & 2.0 & 1.9 & Digit III \\
LM4 & 2.0 & 2.1 & 1.8 \\
LM5 & 1.7 & 1.3 & 2.3 \\
\hline Mean (N) & Digit I & Digit II & - \\
\hline RP (6) & 3.0 & 2.8 & - \\
RM (5) & 2.8 & 2.2 & \\
LP(5) & 2.9 & 2.2 & \\
LM (5) & 2.2 & & \\
\hline
\end{tabular}

For the sake of the following description, the longer traces are regarded as pedes and the shorter traces are regarded as mani. The long (pes) traces are either monodactyl or didactyl—presumably representing variation in the registration of the pes with the substratum-and, where measurable, have acute divarication angles $\left(\sim 0-29^{\circ}\right)$. Remarkably, nearly all pedal traces have digit impressions that are curved in the same direction, thus it is not possible to distinguish between left and right pedes: the digit impressions are arcuate with sharp-to-rounded terminations, and, in the didactyl traces, have one digit (always that on the right side of each impression) slightly longer than the other. Where present, the acutely pointed heel is deeply impressed (Fig. 4.3).

The shorter (manus) morphotype also includes both monodactyl and didactyl traces, the digits of which are typically subtriangular with sharp terminations (Fig. 4.1-4.4). The manual digits are subparallel and the spacing between the digits is greater than that of the pes (Fig. 4.1-4.4; Table 4). A hypex is rarely preserved and thus traces can be interpreted as digitigrade rather than calcigrade (Fig. 4.1-4.4). Nearly all traces (manus and pes) include a sand crescent posterior to the trace (Fig. 4.3). Both morphotypes differ from the Berowra ichnites (AM F145167-145171) in their larger size (Tables 2, 4) and the preservation of the heel and a hypex in at least some of the traces.

\section{Discussion}

Reports of fossilized, subaqueous tetrapod tracks are scattered throughout the literature and pertain to a wide range of 
Table 3. Manus and pes measurements for pace, pace angulation, and stride (AM F145167-145170). LM = left manus; $L P=$ left pes; RM = right manus; $R P=$ right pes.

\begin{tabular}{|c|c|c|c|c|c|c|}
\hline Manus & Pace & Distance $(\mathrm{cm})$ & Pace Angulation & Angulation $\left({ }^{\circ}\right)$ & Stride & Distance $(\mathrm{cm})$ \\
\hline & RM1-LM1 & 22.7 & RM1-LM1-RM2 & 46.8 & RM1-RM2 & 18.0 \\
\hline & RM2-LM2 & 20.7 & RM2-LM2-RM3 & 70.0 & RM3-RM4 & 22.2 \\
\hline & LM2-RM3 & 22.9 & LM2-RM3-LM3 & 69.1 & RM4-RM5 & 23.5 \\
\hline & LM3-RM4 & 20.4 & LM3-RM4-LM4 & 51.5 & LM2-LM3 & 25.8 \\
\hline & RM4-LM4 & 19.5 & RM4-LM4-RM5 & 63.7 & LM3-LM4 & 17.8 \\
\hline & LM4-RM5 & 23.8 & LM4-RM5-LM5 & 82.9 & LM4-LM5 & 31.9 \\
\hline Mean $(\mathrm{N})$ & RM5-LM5 & 21.7 & - & - & - & - \\
\hline \multirow[t]{6}{*}{ Pes } & Pace & Distance $(\mathrm{cm})$ & Pace Angulation & Angulation $\left({ }^{\circ}\right)$ & Stride & Distance $(\mathrm{cm})$ \\
\hline & RP1-LP1 & 24.3 & RP1-LP1-RP2 & 37.1 & RP1-RP2 & 18.9 \\
\hline & LP1-RP2 & 30.7 & LP1-RP2-LP2 & 50.3 & RP2-RP3 & 23.9 \\
\hline & RP2-LP2 & 27.3 & RP2-LP2-RP3 & 49.9 & RP3-RP4 & 22.8 \\
\hline & LP2-RP3 & 29.7 & LP2-RP3-LP3 & 53.6 & RP4-RP5 & 25.5 \\
\hline & RP3-LP3 & 24.9 & RP3-LP3-RP4 & 46.4 & RP5-RP6 & 24.2 \\
\hline \multirow[t]{2}{*}{ Mean $(\mathrm{N})$} & LP-RP (5) & 29.9 & RP-LP-RP & 48.2 & RP-RP (5) & 23.1 \\
\hline & RP-LP (5) & 25.4 & LP-RP-LP & 51.6 & LP-LP (4) & 25.2 \\
\hline
\end{tabular}

taxonomic groups (Peabody, 1948, 1956, 1959; Lammers, 1964; Coombs, 1980; Currie, 1983; McAllister, 1989; McAllister and Kirby, 1998; Milner et al., 2006; Ezquerra et al., 2007; Romilio et al., 2013; Xing et al., 2013; Thomson and Lovelace, 2014; Thomson and Droser, 2015b; Milner and Lockley, 2016). Such traces can be difficult to identify and interpret because they are inherently variable and incomplete.

McAllister (1989) defined several criteria important for interpreting subaqueous marks left by swimming tetrapods based on diverse footmarks from the Dakota Formation in Kansas. These include: (1) posterior overhang of the sediment; (2) reflecture of the digits; (3) a sharp increase in depth of the footmarks corresponding to the arc of a limb during propulsion; (4) elongation of the footmarks; and (5) striations parallel to the direction of movement. Other authors have identified additional criteria useful for distinguishing subaqueous tetrapod traces, however, morphological variation can also be expected from different tracemakers (varying body width/length, locomotor pattern, foot morphology, and speed), substrata (topography, consistency, and composition), and degree of buoyancy (which could be dependent on water depth). In addition to the traces themselves, sedimentological evidence (e.g., lack of shrinkage cracks or salt pseudomorphs, absence of ripple marks) can be useful supplementary evidence for identifying traces made in a subaqueous environment (Peabody, 1948). Regardless, the most important criterion for the recognition of subaqueous traces is evidence of buoyancy (McAllister, 1989).

The Berowra Creek tracks (AM F145167-145171) are interpreted to have been created by a swimming animal that was partially or completely submerged and affected by both buoyancy and current. Evidence supporting this interpretation include: (1) trackways that begin or end abruptly on undisturbed bedding planes with discontinuous sequences that can be laterally shifted from one another (Peabody, 1948; Brand and Tang, 1991); (2) individual prints that are oriented in a different direction from that of the trackway axis (Brand and Tang, 1991); (3) subparallel digit impressions (Brand, 1996); (4) posterior overhang of the sediment (Boyd and Loope, 1984; McAllister, 1989); (5) reflecture of the digits (Boyd and Loope, 1984; McAllister, 1989); (6) elongation of footmarks/toe drags often parallel to the direction of movement (Lockley et al., 1986; McAllister, 1989); and (7) isolated or incomplete digit or pes/ manus impressions (Peabody, 1948; Currie, 1983; Lockley, 1986). Our interpretation therefore differs from the initial assessment of the trackway made by Fletcher (1948), who considered the tracks to have been made subaerially.

Furthermore, the trackmaker is here interpreted to have been travelling in opposition to the flow of water as evidenced by: (1) strong asymmetry between left and right tracks (right manus/pes traces in-turned relative to the trackway axis (Ezquerra et al., 2007); (2) the start and abrupt stop of tracks along the trackway showing incomplete step and stride preservation and the directional shift toward the right of the midline (Brand and Tang, 1991); and (3) the upslope direction of travel in opposition to the dip of the cross beds (paleoflow indicated by the direction of dip of the crossbeds; e.g., Boggs, 2011).

It is unclear whether the associated slab (AM F145166) originated from the Annangrove trackway reported by Sherwin (1969). Several points, however, indicate that AM F145166 was probably not part of the Berowra trackway. Digit lengths are variable but relatively short in AM F145167-145171 (1.3$4.5 \mathrm{~cm}$; Table 2) compared to those on AM F145166 (4.9$12.7 \mathrm{~cm}$; Table 4). In addition, the elongated digits and prominent posterior sand crescents and the occasional presence of a heel and hypices on AM F145166 suggest that the tracemaker was less buoyant (in shallower water) and was able to register more of its weight on the substratum (Brand and Tang, 1991; Brand, 1996). The unusual arrangement of the traces into 'rows' (possibly representing the course of two or more animals) further differentiate them from AM F145167-145171. AM 
Table 4. Digit lengths (cm) for AM F145166. Digits are numbered from the left to right as preserved (see Fig. 4.2) and might not represent the actual digit positions on the skeleton. All measurements were made firsthand.

\begin{tabular}{lcc}
\hline Trace & Digit I & Digit II \\
\hline $\mathbf{1}$ & 8.62 & - \\
$\mathbf{2}$ & 11.0 & 12.7 \\
$\mathbf{3}$ & 10.5 & 10.5 \\
$\mathbf{4}$ & 7.9 & 10.4 \\
$\mathbf{5}$ & 11.9 & 12.6 \\
$\mathbf{6}$ & 5.6 & 5.2 \\
$\mathbf{7}$ & 12.0 & - \\
$\mathbf{8}$ & 5.4 & 5.9 \\
$\mathbf{9}$ & 11.5 & 12.2 \\
$\mathbf{1 0}$ & 4.9 & - \\
$\mathbf{1 1}$ & 8.2 & 9.2 \\
$\mathbf{1 2}$ & 9.0 & - \\
\hline
\end{tabular}

F145166 nevertheless lacks diagnostic features that can be used to confidently identify the trackmaker, although the morphological similarities (mono- and didactyl traces with curved digit impressions) with AM F145167-145171 suggest that they were made by a similar animal (or animals) to the Berowra trackmaker.

Determining the trackmaker.-Because of the incomplete registration of the manus/pes and the vagaries of subaqueously-formed traces, determining the trackmaker(s) for both AM F145167-145171 and AM F145166 is fraught with difficulty. In the absence of more complete manus/pes tracks, the most useful evidence for determining the identity of the Berowra tracemaker is the approximate body length determined by the glenoacetabular length. Unfortunately, there is no overlap of the manus and pes traces, therefore it cannot be determined whether the tracemaker was a short-coupled or long-coupled organism. If the organism was short-coupled, the glenoacetabular length of the tracemaker was, at most, $\sim 37 \mathrm{~cm}$, with a body length of $\sim 80 \mathrm{~cm}$. Alternatively, if the organism was long-coupled, the glenoacetabular length would have been $\sim 50 \mathrm{~cm}$, making the animal $\sim 135 \mathrm{~cm}$ in length. At any rate, these measurements are highly tentative, given that track-derived measurements of glenoacetabular length can be longer than the actual length (Brand and Tang, 1991) and that the trackmaker was at least partially submerged and paddling against a current, making it unlikely that the traces accurately represent the glenoacetabular length.

Most of the known temnospondyls from the Sydney Basin fall well below the estimated body length of the Berowra tracemaker, although most of these are represented by single specimens and/or juveniles (e.g., Notobrachyops picketti, Platycepsion wilkinsoni, Subcyclotosaurus brookvalensis, Watsonisuchus sp.) with body lengths of $<\sim 25 \mathrm{~cm}$ (Warren and Marsicano, 2000; Damiani, 2001; Retallack et al., 2011). Therefore, maximum body lengths are unknown for many taxa.

The largest of the Narrabeen Group amphibians, Bulgosuchus gargantua, has an estimated total body length of $>2.3 \mathrm{~m}$ (Damiani, 1999), which is greater than the body length estimates of the Berowra tracemaker. However, a small B. garantua individual would have been potentially capable of producing traces equivalent in size to those of the Berowra trackway. Similarly, a small individual of Paracyclotosaurus davidi (Wianamatta Group) could conceivably have been responsible for the
Berowra trackway (body length $\sim 2.08 \mathrm{~m}$ based on the only known specimen; Watson, 1958; Retallack et al., 2011). The phalangeal formula of Paracyclotosaurus davidi (both manus and pes 2-2-3-3-2) also indicates that it had two longer digits in both the manus and pes and thus might have been capable of producing primarily didactyl traces under certain subaqueous conditions (Watson, 1958). Whether or not the manual and pedal phalangeal formula of Paracyclotosaurus davidi is exclusive of the other Sydney Basin temnospondyls is unknown because phalangeal material is lacking for these other taxa. Furthermore, the manus and pes of Paracyclotosaurus davidi are morphologically similar (Watson, 1958) and their resulting traces would have been comparable (homopodous), as is also the case for the Berowra trackway. Finally, Microposaurus averyi (also Wianamatta Group) has a skull length of $\sim 40 \mathrm{~cm}$, with an estimated body length of $\sim 1.45 \mathrm{~m}$ (Warren, 2012), which is comparable to the long-coupled body-length estimate of the Berowra tracemaker $(\sim 1.35 \mathrm{~m})$.

The only diagnostic reptile from the Hawkesbury Series, the so-called Long Reef erythrosuchid, is known from only two dorsal vertebrae (Kear, 2009; Ezcurra, 2016). The centra measure $28.9 \mathrm{~mm}$ and $26.3 \mathrm{~mm}$ in height, respectively (Kear, 2009), similar to the anterior dorsal centra of Garjainia madiba Gower et al., 2014 ( 28 mm; Gower et al., 2014), which has a total adult body length estimated at $\sim 2.5 \mathrm{~m}$ (Gower et al., 2014) and which provides an approximate guide to the length of the Long Reef erythrosuchid. Erythrosuchids (including the Long Reef erythrosuchid and G. madiba) probably assumed a sprawling posture in life (Bernardi et al., 2015). Initial suggestions posited that erythrosuchids and proterosuchids were capable of creating Protochirotherium Fichter and Kunz, 2004 footprints (Klein and Neidzwiedzki, 2012; Klein et al., 2013). However, Protochirotherium trackways are narrow and inconsistent with a sprawling trackmaker. Conversely, erythrosuchids might have produced chirotheriid (Abel, 1935) or chirotheriidlike tracks (Bernardi et al., 2015). Chirotheriid or chirotheriidlike footprints differ from the Berowra traces significantly in shape, size, and phalangeal formula (digit arrangement; Bernardi et al., 2015), rendering an erythrosuchid origin unlikely.

The Berowra tracks differ from those of other trackways reported from the Sydney Basin. The amphibian trackmaker reported from the Wianamatta Group had a glenoacetabular length of $106 \mathrm{~cm}$ and digits $>10 \mathrm{~cm}$ long (Pepperell and Grigg, 1974), revealing body proportions at least twice the size of the Berowra trackmaker. Moreover, these tracks were made in a subaerial setting and preserve clear tetradactyl pes and tridactyl manus pairings that differentiate them from the Berowra tracks.

Therapsid tracks (Dicynodontipus bellambiensis) from the Coalcliff Sandstone show pentadactyl manus and pes pairings consistent with a phalangeal formula of 2-3-3-3-3 (Retallack, 1996). With an estimated body length of $\sim 84 \mathrm{~cm}$, the D. bellambiensis trackmaker is intermediate between the short- and longcoupled tracemaker estimates for the Berowra tracemaker. The Berowra traces show a manus pace angulation that is greater than the pes pace angulation, indicative of an amphibian or reptile affinity (Leonardi, 1987) and similar to D. bellambiensis (see Retallack, 1996). If our assumption is correct (that digits of III and IV of the Berowra tracemaker were longer than the 
remaining digits), the phalangeal formula of $D$. bellambiensis (2-3-3-3-3) is inconsistent with the traces created by the Berowra trackmaker. In addition to being made in different settings (subaerial versus subaqueous), D. bellambiensis tracks are also outwardly curved from the midline, rather than the slightly in-turned or parallel tracks displayed by the Berowra trackway (Fig. 1).

In summary, the Berowra trackway (AM F145167145171) and, by extension, AM F145166, differs from all reported trackways from the Hawkesbury Series, the latter of which were all made under subaerial conditions. Whereas reptilian and therapsid origins are unlikely, at least three temnospondyls from the Hawkesbury Series fall within the range of body length estimates for the Berowra trackmaker and provide tenable candidates for the formation of these traces.

Ichnotaxonomic considerations. - Swim trace ichnotaxonomy is ideally based on the number of digits and the relative lengths and widths of their impressions (Lockley and Foster, 2006). Characichnos Whyte and Romano, 2001 has traditionally been reserved for subaqueous tridactyl traces made by theropods (see Milner and Lockley, 2016) whose body-fossil record postdates the Hawkesbury traces by $\sim 15$ Myr. Nevertheless, Characichnos has also been applied to traces produced by a variety of nontheropod tracemakers, including phytosaurs (Milner et al., 2006), basal crocodylomorphs (Milner et al., 2006), crocodilians (Vila et al., 2015), and indeterminate reptiles (Boyd and Loope, 1984; McAllister and Kirby, 1998; Thomson and Lovelace, 2014; see also Milner and Lockley, 2016 and references therein). Hunt and Lucas (2007) even considered a Characichnos ichnofacies, which incorporated parallel scratch marks assigned to Characichnos and Hatcherichnus Foster and Lockley, 1997 (see below). Although commonly tridactyl, the number of digits is highly variable (from two to five in Characichnos) even within a single trace assemblage (Vila et al., 2015), although Milner and Lockley (2016) considered (pes) traces with four or more digits referable to the crocodilian ichnogenus, Hatcherichnus (see also Foster and Lockley, 1997; Lockley and Foster, 2006). The obviously quadrupedal Hawkesbury tracemaker differs from bipedal theropod swim traces (e.g., Characichnos, and possibly Wintonopus Romilio, Tucker, and Salisbury, 2013)including the didactyl Paravipes Mudroch et al., 2010 (see Milner and Lockley, 2016) - and from crocodylomorphs (Hatcherichnus, Albertasuchipes McCrea, Pemberton, and Currie, 2004), which typically have higher digit counts (Foster and Lockley, 1997; McCrea et al., 2004; Milner and Lockley, 2016).

Amphibian swim traces are globally rare (Braddy et al., 2003). Most of these have been assigned to the ichnogenus Lunichnium Walter, 1983, which has been considered by some authors as forming a continuum with the walking ichnogenus Batrachichnus Woodworth, 1900 and which Petti et al. (2014) denoted as Batrachichnus C Lunichnium (where the C stands for continuum). Serpentichnus Braddy et al., 2003 from the early Permian of New Mexico represents an unusual 'sidewinding' form of locomotion by a possible lysorophian tracemaker (Braddy et al., 2003) that is distinct from the Hawkesbury traces. Walter (1983) erected Lunichnium on the basis of material from the early Permian of Germany that he interpreted as the trackway of a swimming arthropod. Turek (1989) later reinterpreted these as temnospondyl swim traces based on additional material from the upper Carboniferous of the Czech Republic. Minter and Braddy (2006, p. 1134) diagnosed Lunichnium as trackways composed of 'discrete, paired curvilinear imprints that can bifurcate and are curved concave outwards' and symmetrical between left and right sides. Following the reasoning of Petti et al. (2014), this definition cannot be used in isolation and naturally includes a broad spectrum of morphotypes along the Batrachichnus C Lunichnium continuum.

Nevertheless, the swim traces (i.e., Lunichnium, as defined by Minter and Braddy, 2006) compare poorly with those reported here from the Hawkesbury Sandstone; most of the didactyl traces described here consist of paired (not bifurcated), linear scratch marks that are rarely curved (in which case they are concave medially [e.g., Fig. 3.2, slabs E and F]; unclear in AM F145166) and strongly asymmetrical between left and right sides. AM F145166 does, on the other hand, include some bifurcated traces (Fig. 4.2) that bear some resemblance to the holotype of Lunichnium (Walter, 1983). Many of the observed differences can probably be ascribed to differences in locomotion, water depth, current direction, substratum type/consistency, or any combination of these. We therefore refrain from assigning either AM F145167-145171 or AM F145166 to a particular ichnotaxon, but recognize their similarities (and distinctions) to Lunichnium-type amphibian traces.

AM F145167-145171 and AM F145166 therefore represent a unique, potentially amphibian (temnospondyl) trace type and the oldest tetrapod swimming traces from Australia. Australian tetrapod trackways that predate the Hawkesbury traces are limited to only three possible occurrences. One of these, from the Grampians region of Victoria (the 'Glenisla' homestead tracks), is either late Silurian or earliest Devonian in age and might not have been made by a tetrapod at all because these dates potentially predate the fish-tetrapod transition (Young, 2006). The Glenisla trackway, even if representative of a tetrapod, is thought to have been produced subaerially (Warren et al., 1986; Gouramanis et al., 2003) and therefore does not represent a trackway comparable to the Berowra traces. Two additional trackways have been described from the Upper Devonian Merrimbula Group in Victoria. One of these shows digit impressions directed at right angles to the body, which suggests a different wrist and ankle configuration to the typical anteriorly directed early-tetrapod footprints (Young, 2006). The second trackway preserves a sinuous tail trace and manus impressions that are much smaller than those of the pes, similar those of the tetrapod Tulerpeton Lebedev, 1984 (Clack, 1997; Young, 2006). Associated mudcracks at the locality suggest a subaerial formation or, alternatively, a trackway created by a tetrapod walking through shallow water (Clack, 1997; Young, 2006).

\section{Conclusions}

A reanalysis of a succession of unusual, wide-gauge, primarily didactyl traces from the Middle Triassic Hawkesbury Sandstone identifies these as the swimming traces of a buoyant or partially 
buoyant, large-bodied tetrapod (possibly amphibian; body length $\sim 80-135 \mathrm{~cm}$ ) tracemaker. These findings are in opposition to the original interpretation made by Fletcher (1948) who attributed the tracks to an unknown pentadactyl terrestrial reptile walking along an ancient shoreline.

Because swim traces do not accurately represent the true manual/pedal morphology of the trackmaker, confident identification of the animal is difficult. The primarily didactyl manus/pes traces show limited similarity to other quadrupedal amphibian swim traces in the Batrachichnus C Lunichnium continuum, but are unique in the linear arrangement of the digit impression and strong asymmetry between left and right sides. Trackway measurements do not match those of any known tetrapod from the Sydney Basin, although the temnospondyls Bulgosuchus gargantua, Microposaurus averyi, and Paracyclotosaurus davidi provide suitable candidates for the Berowra tracemaker based on body length estimates. Caution is nevertheless advised because our body length estimates for the Berowra trackmaker are based on tracks produced under subaqueous conditions. The primarily didactyl tracks could be the product of an individual that had two longer digits in the manus and pes, similar to Paracyclotosaurus davidi, but whether this condition is unique to Paracyclotosaurus davidi or shared among other Australian temnospondyls is unknown.

Although historically neglected because of its ambiguity, the two Hawkesbury trackways reported here are important because they represent the oldest tetrapod swimming trackways from Australia and a unique swimming morphotype of possible amphibian origin. These data contribute to the limited but important fossil record of the Hawkesbury Series, which is considered the best Australian Early to Middle Triassic terrestrial fauna. Although the identity of the trackmaker remains ambiguous, the Hawkesbury tracks further demonstrate the contribution of ichnology to the understanding of the Sydney Basin fauna.

\section{Acknowledgments}

We thank D. McGeeny, R. Pogson, A. Dejanovic, and C. Macgregor from the Australian Museum for specimen access; T. Mansson for creating casts of some of the ichnites; P. Egan and G. McLean for helping to locate archival images pivotal to this paper; and P. Smith for help with specimen numbers. Thanks also to A. Bell for assistance creating Fig. 2.1 and S. Poropat for advice and locating papers. M. White and A. Romilio provided helpful comments on an earlier version of the manuscript. We thank the editors, H.-D. Sues and J. Kastigar, as well as M. Lockley and T. Thomson, for their thoughtful reviews of the manuscript and providing helpful comments. Special thanks to L. Farman, O. Moreano Cuellar, M. Farman, and E. McCarthy for their support. This research was supported by an Australian Research Council Discovery Early Career Researcher Award (project ID: DE170101325) to PRB.

\section{References}

Abel, O., 1935, Vorzeitliche Lebensspuren: Jena, G. Fischer, 644 p.

Azerêdo, A., 1993, Jurássico médio do maciço calcário estremenho (Bacia Lusitânica): Análise de fácies, micropaleontologia, paleogeografia [Ph.D. dissertation]: Lisbon, Universidade de Lisboa, 366 p.
Azerêdo, A., Ramalho, M., Santos, V., and Galopim de Carvalho, A., 1995, Calcários com pegadas de dinossáurios da Serra d'Aire: Microfácies e paleoambientes: Gaia, v. 11, p. 1-6.

Baird, D., 1957, Triassic reptile footprint faunules from Milford, New Jersey: Bulletin of the Museum of Comparative Zoology, v. 117, p. 449-520.

Bernardi, M., Klein, H., Petti, F.M., and Ezcurra, M.D., 2015, The origin and early radiation of Archosauriforms: Integrating the skeletal and footprint record: PLOS One, v. 10, no. 6, p. 1-28, doi:10.1371/journal. pone. 0128449 .

Boggs, S., Jr., 2011, Principles of Sedimentology and Stratigraphy: Cambridge, Pearson, $583 \mathrm{p}$.

Boyd, D.W., and Loope, D.B., 1984, Probable vertebrate origin for certain sole marks in Triassic red beds of Wyoming: Journal of Paleontology, v. 58, p. $467-476$.

Braddy, S.J., Morrissey, L.B., and Yates, A.M., 2003, Amphibian swimming traces from the lower Permian of southern New Mexico: Palaeontology, v. 46, p. 671-683, doi:10.1111/1475-4983.00315.

Brand, L.R., 1996, Variations in salamander trackways resulting from substrate differences: Journal of Paleontology, v. 70, p. 1004-1010.

Brand, L.R., and Tang, T., 1991, Fossil vertebrate footprints in the Coconino Sandstone (Permian) of northern Arizona: Evidence for underwater origin: Geology, v. 19, p. 1201-1204.

Carpenter, K., 2009, Role of lateral body bending in crocodylian track making: Ichnos, v. 16, p. 202-207, doi:10.1080/10420940802686137.

Clack, J.A., 1997, Devonian tetrapod trackways and trackmakers: A review of the fossils and footprints: Palaeogeography, Palaeoclimatology, Palaeoecology, v. 130, p. 227-250.

Coombs, W.P., 1980, Swimming ability of carnivorous dinosaurs: Science, v. 207 , p. $1198-1200$.

Cosgriff, J.W., 1973, Notobrachyops picketti, a brachyopid from the Ashfield Shale, Wiannamatta Group, New South Wales: Journal of Paleontology, v. 47 , p. $1094-1101$

Currie, P.J., 1983, Hadrosaur trackways from the Lower Cretaceous of Canada: Acta Palaeontologica Polonica, v. 28, p. 62-74.

Damiani, R.J., 1999, Giant temnospondyl amphibians from the Early to Middle Triassic Narrabeen Group of the Sydney Basin, New South Wales, Australia: Alcheringa, v. 23, p. 87-109.

Damiani, R.J., 2001, A systematic revision and phylogenetic analysis of Triassic mastodonsauroids (Temnospondyli: Stereospondyli): Zoological Journal of the Linnean Society, v. 133, p. 379-482, doi:10.1006/zjls.2001.0304.

Damiani, R.J., and Warren, A.A., 1997, Re-interpretation of Parotosuchus wadei Cosgriff, a capitosaurid from the Triassic Narrabeen Group at Gosford, New South Wales, with comments on its growth stage: Alcheringa, v. 21, p. 281-289.

Day, J.J., Upchurch, P., Norman, D.B., Gale, A.S., and Powell, H.P., 2002, Sauropod trackways, evolution, and behavior: Science, v. 296, p. 1659, doi: $10.1126 /$ science. 1070167.

Ezcurra, M.D., 2016, The phylogenetic relationships of basal archosauromorphs, with an emphasis on the systematics of proterosuchian archosauriforms: PeerJ, v. 4, p. e1778, doi:10.7717/peerj.1778.

Ezquerra, R., Doublet, S., Costeur, L., Galton, P.M., and Pérez-Lorente, F., 2007, Were non-avian theropod dinosaurs able to swim? Supportive evidence from an Early Cretaceous trackway, Cameros Basin (La Rioja, Spain): Geology, v. 35, p. 507-510, doi:10.1130/G23452A.1.

Fichter, J., and Kunz, R., 2004, New genus and species of chirotheroid tracks in the Detfurth-Formation (middle Bunter, Lower Triassic) of central Germany: Ichnos, v. 11, p. 183-193, doi:10.1080/104209404 90444997.

Fletcher, H.O., 1948, Footprints in the sands of time: Australian Museum Magazine, p. 247-251.

Foster, J.R., and Lockley, M.G., 1997, Probable crocodilian tracks and traces from the Morrison Formation (Upper Jurassic) of eastern Utah: Ichnos, v. 5 , p. 121-129.

Ginsburg, L., Lapparent, A.F., Loiret, B., and Taquet, P., 1966, Empreintes de pas de vertébrés tetrapodes dans les séries continentales à l'Ouest d'Agades (République du Niger): Comptes Rendus Hebdomadaires des Seances de l'Académie des Sciences, v. 263, p. 28-31.

Gouramanis, C., Webb, J., and Warren, A.A., 2003, Fluviodeltaic sedimentology and ichnology of part of the Silurian Grampians Group, western Victoria: Australian Journal of Earth Sciences, v. 50, p. 811-825, doi:10.1111/j.1440-0952.2003.01028.x.

Gower, D.J., Hancox, P.J., Botha-Brink, J., Sennikov, A.G., and Butler, R.J., 2014, A new species of Garjainia Ochev, 1958 (Diapsida: Archosauriformes: Erythrosuchidae) from the Early Triassic of South Africa: PLOS One, v. 9, no. 11, p. 1-35, doi:10.1371/journal.pone.0111154.

Helby, R., 1969, Plant microfossils in the Hawkesbury Sandstone, in Packham, G.H., ed., The Geology of New South Wales: Sydney, Geological Society of Australia, p. 417 
Herbert, C., 1980, Depostional development of the Sydney Basin, in Herbert, C., and Helby, R., eds., A Guide to the Sydney Basin: Geological Survey of New South Wales Bulletin, v. 26, p. 11-25.

Herbert, C., 1983, Sydney Basin stratigraphy, in Herbert, C., ed., Geology of the Sydney 1:100,000 Sheet 9130: Sydney, New South Wales Department of Natural Resources, p. 7-34.

Herbert, C., 1997, Sequence stratigraphic analysis of Early and Middle Triassic alluvial and estuarine fades in the Sydney Basin, Australia: Australian Journal of Earth Sciences, v. 44, p. 125-143.

Huene, F. von, 1913, A new phytosaur from the Palisades near New York: Bulletin of the American Museum of Natural History, v. 32, p. 275-282.

Hunt, A.P., and Lucas, S.G., 2007, Tetrapod ichnofacies: A new paradigm: Ichnos, v. 14, p. 59-68, doi:10.1080/10420940601006826.

Kear, B.P., 2009, Proterosuchid archosaur remains from the Early Triassic Bulgo Sandstone of Long Reef, New South Wales: Alcheringa, v. 33, p. 331-337, doi:10.1080/03115510903270944.

Kear, B.P., and Hamilton-Bruce, R.J., 2011, Dinosaurs in Australia: Mesozoic Life from the Southern Continent: Collingwood, CSIRO Publishing, $200 \mathrm{p}$.

Klein, H., and Lucas, S.G., 2010a, Review of the tetrapod ichnofauna of the Moenkopi Formation/Group (Early-Middle Triassic) of the American southwest: New Mexico Museum of Natural History and Science Bulletin, v. 50, p. $1-68$.

Klein, H., and Lucas, S.G., 2010b, Tetrapod footprints-Their use in biostratigraphy and biochronology of the Triassic: Geological Society London Special Publications, v. 334, p. 419-446, doi:10.1144/SP334.14.

Klein, H., and Neidzwiedzki, G., 2012, Revision of the Lower Triassic tetrapod ichnofauna from Wióry, Holy Cross Mountains, Poland: New Mexico Museum of Natural History and Science Bulletin, v. 56, p. 1-62.

Klein, H., Niedźwiedzki, G., Voigt, S., Lagnaoui, A., Hminna, A., Saber, H., and Schneider, J.W., 2013, The tetrapod ichnogenus Protochirotherium Fichter and Kunz 2004, a characteristic Early Triassic morphotype of central Pangea: Ichnos, v. 20, p. 24-30, doi:10.1080/10420940.2012.757699.

Lammers, G.E., 1964, Reptile tracks and the paleoenvironment of the Triassic Moenkopi of Capitol Reef National Monument, Utah, in Colton, H.S., ed., Contributions to the Geology of Northern Arizona: Major Brady Memorial Museum of Northern Arizona Bulletin, v. 40, p. 49-55.

Lebedev, O.A., 1984, The first find of a Devonian tetrapod in the USSR: Doklady Academii Nauk SSSR, v. 278, p. 1470-1473.

Leonardi, G., 1987, Glossary and Manual of Tetrapod Footprint Palaeoichnology: Brasília, Publicação do Departemento Nacional da Produção Mineral Brasil, $75 \mathrm{p}$.

Lockley, M., and Meyer, C., 2000, Dinosaur Tracks and Other Fossil Footprints of Europe: New York, Columbia University Press, 360 p.

Lockley, M.G., 1986, The paleobiological and paleoenvironmental importance of dinosaur footprints: Palaios, v. 1, p. 37-47.

Lockley, M.G., and Foster, J.R., 2006, Dinosaur and turtle tracks from the Morrisson Formation (Upper Jurassic) of Colorado National Monument, with observations on the taxonomy of vertebrate swim tracks, in Foster, J.R., and Lucas, S.G., eds., Paleontology and Geology of the Upper Jurassic Morrison Formation: New Mexico Museum of Nature and Science Bulletin, v. 36, p. 193-198.

Lockley, M.G., Houck, K.J., and Prince, N.K., 1986, North America's largest dinosaur trackway site: Implications for Morrison Formation paleoecology: Geological Society of America Bulletin, v. 97, p. 1163-1176.

Lucas, S.G., 1998, Global Triassic tetrapod biostratigraphy and biochronology: Palaeogeography, Palaeoclimatology, Palaeoecology, v. 143, p. 347-384.

Marchetti, L., Santi, G., and Avanzini, M., 2014, The problem of small footprints in paleoichnology: Remarks on the early Permian ichnotaxon Erpetopus cassinisi, a local species from Southern Alps (northern Italy): Rivista Italiana di Paleontologia e Stratigrafia, v. 120, p. 129-143.

Martin, A.J., 2014, Dinosaurs Without Bones: Dinosaur Lives Revealed by their Trace Fossils: New York, Pegasus Books, 400 p.

McAllister, J., 1989, Dakota Formation tracks from Kansas: Implications for the recognition of tetrapod subaqueous traces, in Gillette, D.D., and Lockley, M.G., eds., Dinosaur Tracks and Traces: Cambridge, Cambridge University Press, p. 343-348.

McAllister, J., and Kirby, J., 1998, An occurrence of reptile subaqueous traces in the Moenkopi Formation (Triassic) of Capitol Reef National Park, south central Utah, USA: Journal of the Pennsylvania Academy of Science, v. 71, p. $174-181$.

McCrea, R.T., Pemberton, S.G., and Currie, P.J., 2004, New ichnotaxa of mammal and reptile tracks from the upper Paleocene of Alberta: Ichnos, v. 11, p. 323-339, doi:10.1080/10420940490442313.

Miall, A.D., 1977, A review of the braided-river depositional environment: Earth-Science Reviews, v. 13, p. 1-62.

Miall, A.D., and Jones, B.G., 2003, Fluvial architecture of the Hawkesbury Sandstone (Triassic), near Sydney, Australia: Journal of Sedimentary Research, v. 73, p. 531-545, doi:10.1306/111502730531.
Milner, A., and Lockley, M.G., 2016, Dinosaur swim track assemblages: Characteristics, contexts, and ichnofacies implications, in Falkingham, P.L., Marty, D., and Richter, A., eds., Dinosaur Tracks: Bloomington, Indiana University Press, p. 153-181.

Milner, A.R., Lockley, M.G., and Kirkland, J.I., 2006, A large collection of well-preserved theropod dinosaur swim tracks from the Lower Jurassic Moenave Formation, St. George, Utah, in Harris, J.D., Lucas, S.G., Spielmann, J.A., Lockley, M.G., Milner, A.R.C., and Kirkland, J.I., eds., The Triassic-Jurassic Terrestrial Transition: New Mexico Museum Natural History and Science Bulletin, v. 37, p. 315-328.

Minter, N.J., and Braddy, S.J., 2006, The fish and amphibian swimming traces Undichna and Lunichnium, with examples from the lower Permian of New Mexico, USA: Palaeontology, v. 49, p. 1123-1142, doi:10.1111/j.14754983.2006.00588.x.

Mudroch, A., Richter, U., Joger, U., Kosma, R., Idé, O., and Maga, A., 2010, Didactyl tracks of paravian theropods (Maniraptora) from the ?Middle Jurassic of Africa: PLoS One, v. 6, no. 2, p. 1-10, doi:10.1371/journal. pone.0014642.

Padian, K., and Olsen, P.E., 1984a, Footprints of the Komodo monitor and the trackways of fossil reptiles: Copeia, v. 1984, no. 3, p. 662-671.

Padian, K., and Olsen, P.E., 1984b, The fossil trackway Pteraichnus: Not pterosaurian, but crocodilian: Journal of Paleontology, v. 58, p. 178-184.

Peabody, F.E., 1948, Reptile and amphibian trackways from the Lower Triassic Moenkopi Formation of Arizona and Utah: University of California Publications, Bulletin of the Department of Geological Sciences, v. 27, p. 295-468.

Peabody, F.E., 1956, Ichnites from the Triassic Moenkopi Formation of Arizona and Utah: Journal of Paleontology, v. 30, p. 731-740.

Peabody, F.E., 1959, Trackways of living and fossil salamanders: University of California Publications in Zoology, v. 63, p. 1-72.

Pepperell, J., and Grigg, G., 1974, A labyrinthodont trackway from the MidTriassic near Sydney, New South Wales: Proceedings of the Linnean Society of New South Wales, v. 99, p. 54-56.

Petti, F.M., Bernardi, M., Ashley-Ross, M.A., Berra, F., Tessarollo, A., and Avanzini, M., 2014, Transition between terrestrial-submerged walking and swimming revealed by early Permian amphibian trackways and a new proposal for the nomenclature of compound trace fossils: Palaeogeography, Palaeoclimatology, Palaeoecology, v. 410, p. 278-289, doi:10.1016/ j.palaeo.2014.05.032.

Retallack, G.J., 1996, Early Triassic therapsid footprints from the Sydney Basin, Australia: Alcheringa, v. 20, p. 301-314.

Retallack, G.J., Sheldon, N.D., Carr, P.F., Fanning, M., Thompson, C.A., Williams, M.L., Jones, B.G., and Hutton, A., 2011, Multiple Early Triassic greenhouse crises impeded recovery from late Permian mass extinction: Palaeogeography, Palaeoclimatology, Palaeoecology, v. 308, p. 233-251, doi:10.1016/j.palaeo.2010.09.022

Rogers, K.C., and Wilson, J., 2005, The Sauropods: Evolution and Paleobiology: Berkeley, University of California Press, $349 \mathrm{p}$.

Romilio, A., Tucker, R.T., and Salisbury, S.W., 2013, Reevaluation of the Lark Quarry dinosaur tracksite (late Albian-Cenomanian Winton Formation, central-western Queensland, Australia): No longer a stampede?: Journal of Vertebrate Paleontology, v. 33, p. 102-120, doi:10.1080/02724634.2012. 694591.

Rust, B.R., and Jones, B.G., 1987, The Hawkesbury Sandstone south of Sydney, Australia: Triassic analogue for the deposit of a large, braided river: Journal of Sedimentary Petrology, v. 57, p. 222-233.

Santos, V.F., Moratalla, J.J., and Royo-Torres, R., 2009, New sauropod trackways from the Middle Jurassic of Portugal: Acta Palaeontologica Polonica, v. 54, p. 409-422, doi:10.4202/app.2008.0049.

Sarjeant, W.A., and Stringer, P., 1978, Triassic reptile tracks in the Lepreau Formation, southern New Brunswick, Canada: Canadian Journal of Earth Sciences, v. 15 , p. $594-602$.

Sherwin, L., 1969, Amphibian footprints as an indication of the depth of the deposition of the Hawkesbury Sandstone, in Proceedings, Symposium on Advances in the Study of the Sydney Basin, $4^{\text {th }}$, Newcastle: Newcastle, University of Newcastle, p. 69-70.

Standard, J.C., 1969, Hawkesbury Sandstone in Packham, G.H, ed., The Geology of New South Wales: Sydney, Geological Society of Australia, v. 16, p. $407-415$.

Stephens, W., 1887, On some additional labyrinthodont fossils from the Hawkesbury sandstones of New South Wales (Platyceps wilkinsoni, and two unnamed specimens): Proceedings of the Linnean Society of New South Wales, v. 1, p. 1175-1192.

Thomson, T.J., and Droser, M.L., 2015a, GSA Data Repository item 2015076, swim-track occurences through time: http://geosociety.org/datarepository/ 2015/2015076 (accessed October 2017).

Thomson, T.J., and Droser, M.L., 2015b, Swimming reptiles make their mark in the Early Triassic: Delayed ecologic recovery increased the preservation potential of vertebrate swim tracks: Geology, v. 43, p. 215-218, doi: $10.1130 / \mathrm{G} 36332.1$ 
Thomson, T.J., and Lovelace, D.M., 2014, Swim track morphotypes and new track localities from the Moenkopi and Red Peak formations (Lower-Middle Triassic) with preliminary interpretations of aquatic behaviors: New Mexico Museum of Natural History and Science Bulletin, v. 62, p. 103 128.

Thulborn, T., 1990, Dinosaur Tracks: London, Chapman and Hall, 424 p.

Totterdell, J., Bradshaw, M., Owen, K., Hashimoto, T., and Hall, L., 2014, Petroleum geology inventory of Australia's offshore frontier basins: Geoscience Australia, Canberra, Record 2014/09. http.//dx.doi.org/10.11636/ Record.2014.009.

Turek, V., 1989, Fish and amphibian trace fossils from Westphalian sediments of Bohemia: Palaeontology, v. 32, p. 623-643.

Vila, B., Castanera, D., Marmi, J., Canudo, J.I., and Galobart, À., 2015, Crocodile swim tracks from the latest Cretaceous of Europe: Lethaia, v. 48, p. 256266, doi:10.1111/let.12103.

Walter, H., 1983, Zur Taxonomie, Ökologie und Biostratigraphie der Ichnia limnisch-terrestrischer Arthropoden des mitteleuropäischen Jungpaläozoikums: Freiberger Forschungshefte, v. C382, p. 146-193.

Warren, A.A., 2012, The South African stereospondyl Microposaurus from the Middle Triassic of the Sydney Basin, Australia: Journal of Vertebrate Paleontology, v. 32, p. 538-544, doi:10.1080/02724634.2012.658934.

Warren, A.A., and Marsicano, C., 2000, A phylogeny of the Brachyopoidea (Temnospondyli, Stereospondyli): Journal of Vertebrate Paleontology, v. 20, p. 462 483, doi:10.1671/0272-4634(2000)020[0462:APOTBT]2.0.CO;2.

Warren, A.A., Jupp, R., and Bolton, B., 1986, Earliest tetrapod trackway: Alcheringa v. 10, p. 183-186.

Watson, D.M.S, 1958, A new labyrinthodont (Paracyclotosaurus) from the Upper Triassic of New South Wales: Bulletin of the British Museum of Natural History, Geology, v. 3, p. 233-264.
Whyte, M.A., and Romano, M., 2001, A dinosaur ichnocoenosis from the Middle Jurassic of Yorkshire, UK: Ichnos, v. 8, p. 223-234, doi:10.1080/ 1042094010980189.

Willis, P., and Thomas, A., 2005, Digging Up Deep Time: Fossils, Dinosaurs and Megabeasts from Australia's Distant Past: Sydney, ABC Books, 294 p.

Wilson, J.A., and Carrano, M.T., 1999, Titanosaurs and the origin of 'widegauge' trackways: A biomechanical and systematic perspective on sauropod locomotion: Paleobiology, v. 25, p. 252-267.

Woodworth, J.B., 1900, Vertebrate footprints on Carboniferous shales of Plainville, Massachusetts: Bulletin of the Geological Society of America, v. 11, p. 449-454.

Xing, L., Lockley, M.G., Zhang, J., Milner, A.R., Klein, H., Li, D., Persons, W.S., and Ebi, J., 2013, A new Early Cretaceous dinosaur track assemblage and the first definite non-avian theropod swim trackway from China: Chinese Science Bulletin, v. 58, p. 2370-2378, doi:10.1007/s11434-0135802-6.

Young, G.C., 1996, Devonian (Chart 4), in Young, G.C., and Laurie, J.R., eds . An Australian Phanerozoic Timescale: Melbourne, Oxford University Press, p. 96-109.

Young, G.C., 2006, Biostratigraphic and biogeographic context for tetrapod origins during the Devonian: Australian evidence, in Reed, L., Bourne, S., Megirian, D., Prideaux, G., Young, G., and Wright, A., eds., Proceedings of CAVEPS 2005: Alcheringa, v. 30, suppl. 1, p. 409-428, doi:10.1080/ 03115510608619594.

Accepted: 31 March 2020 